\title{
Pengembangan Media Pembelajaran GeoGebra Classroom Sebagai Penguatan Pemahaman Konsep Materi Translasi Siswa SMP Kelas IX
}

\author{
Naomi Angeltia Sutopo ${ }^{1}$, Novisita Ratu ${ }^{2}$ \\ ${ }^{1,2}$ Program Studimatematika, Fakultas Keguruan Dan Ilmu Pendidikan Universitas Kristen Satya Wacana, \\ Jl. Dipoenegoro 52-60, Salatiga Kec. Sidorejo, Kota Salatiga, Jawa Tengah 500711 \\ 202017006@student.uksw.edu
}

\begin{abstract}
This study aims to develop learning media GeoGebra Classroom as strengthening students' understanding of the concept of translation material. This study uses the R\&D method using the ADDIE model to develop the GeoGebra Classroom media. The subjects in this study were 15 junior high school students in class IX. The types of data used are qualitative and quantitative data, with data collection techniques used in the form of tests and student opinion questionnaires. This study shows media validation results with an average validity value of 4.35 and has an average value of 4.35 media practicality results which are included in the practical category. The results showed an increase in student test results after using the GeoGebra Classroom media as a learning medium for translational material, based on the t-test test of the pretest and posttest showing the value of $\mathrm{p}=$ 0.000 ( $\mathrm{p}<0.05$ ) or the average pretest and posttest were different. $\mathrm{P}$ value $<0.05$ with learning outcomes in the posttest (95.93) better than the pretest (63.33), so this media is included in the effective category. Based on the practicality data analysis, the average score was 43.5 with the average score for all aspects of 4.4 and included in the practical category. From the results of the questionnaire analysis, students' opinions get a score of 3.3 which states that students agree that the GeoGebra Classroom learning media supports and facilitates the learning process. So, it can be concluded that this media is effective and practical if it is used as a medium for learning translation materials for junior high school students.
\end{abstract}

Keywords: GeoGebra Classroom, Conceptual Understanding

\begin{abstract}
Abstrak
Penelitian ini bertujuan untuk mengembangkan media pembelajaran GeoGebraClassroom sebagai penguatkan pemahaman konsep siswa pada materi translasi. Penelitian ini menggunakan metode R\&D dengan menggunakan model ADDIE untuk mengembangkan media GeoGebra Classroom. Subjek pada penelitian ini adalah 15 siswa SMP kelas IX. Jenis data yang digunakan berupa data kualitatif dan kuantitatif, dengan teknik pengumpulan data yang digunakan adalah berupa tes dan angket pendapat siswa. Penelitian ini menunjukkan hasil yang validasi media dengan nilai validitas rata-rata 4,35 serta memiliki nilai rata-rata hasil kepraktisan media sebesar 4,35 yang termasuk dalam kategori praktis. Hasil penelitian menunjukkan adanya peningkatan hasil tes siswa setelah menggunakan media GeoGebra Classroom sebagai media pembelajaran pada materi translasi, berdasarkan uji $t$-test dari pretest dan posttest menunjukkan nilai $\mathrm{p}=0,000(\mathrm{p}<0,05)$ atau rata-rata pretest dan posttest adalah berbeda. Nilai $\mathrm{p}<0,05$ dengan hasil belajar pada posttest $(95,93)$ lebih baik dari pretest $(63,33)$, sehingga media ini temasuk dalam kategori efektif. Berdasarkan analisis data kepraktisan diperoleh rerata skor 43,5 dengan rerata skor semua aspek 4,4 dan termasuk dalam kategori praktis. Dari hasil analisis angket pendapat siswa mendapatkan skor 3,3 yang menyatakan siswa setuju bahwa media pembelajaran GeoGebra Classroom mendukung dan mempermudah proses pembelajaran. Sehingga dapat disimpulkan bahwa media ini efektif dan praktis jika digunakan untuk menjadi media pembelajaran materi translasi untuk siswa tingkat SMP.
\end{abstract}

Kata kunci: GeoGebra Classroom, Pemahaman Konsep

Copyright (c) 2021 Naomi Angelita Sutopo, Novisita Ratu

$\triangle$ Corresponding author: Novisita Ratu

Email Address: novisita.ratu@uksw.edu (J1. Diponegoro No 52-60, Salatiga, Kec.Sidorejo, Salatiga)

Received 02 August 2021, Accepted 13 November 2021, Published 13 December 2021

\section{PENDAHULUAN}

Saat ini kita telah memasuki era revolusi industri 4.0 yang mengacu pada penggunaan sistem digital dalam kehidupan manusia (Kemristekdikti, 2018). Hal tersebut mengakibatkan pesatnya perkembangan teknologi pada saat ini di semua sektor kehidupan, termasuk pada dunia 
pendidikan. Dengan berkembangnya dunia pendidikan saat ini, maka perlu dilakukan berbagai inovasi dalam media pembelajaran yang berbasis pada teknologi. Media yang dikembangkan tersebut dapat meningkatkan proses pembelajaran yang lebih menarik dan dapat menyiapkan siswa agar dapat mengikuti perkembangan zaman (Kowiyah \& Sakti, 2018). Salah satu perkembangan zaman dalam dunia pendidikan adalah pada pelajaran matematika.

Matematika menjadi salah satu mata pelajaran yang dianggap penting di Indonesia, akan tetapi menurut Putra (2016) siswa di Indonesia menganggap bahwa pelajaran matematika sebagai sebuah mata pelajaran yang sulit dipahami dan menakutkan. Sejauh ini siswa lebih cenderung mempelajari matematika dengan cara menghafalkan rumus namun tidak memahaminya, meniru cara guru dalam mengerjakan contoh soal, dan kurangnya pemahaman konsep dalam pembelajaran (Putra, 2017). Halhal tersebut dapat menyebabkan siswa sulit dan kurang maksimal dalam mempelajari matematika. Sehingga dapat menimbulkan rendahnya nilai pendidikan pada bidang matematika di Indonesia. Berdasarkan data survei TIMSS pada tahun2011, Indonesia berada pada posisi peringkat ke-38 dari 45 negara dengan nilai 368, sedangkan rata-rata dari 45 negara tersebut adalah 500. Hal tersebut menunjukkan bahwa untuk pelajaran matematika Indonesia masih berada jauh dibawah nilai rata-rata yang ada dari 45 negara. TIMSS memiliki nilai standar Internasional yaitu untuk kategori rendah dengan nilai 400, sedang memiliki nilai 475, tinggi dengan nilai 550 serta untuk tingkat mahir dengan nilai 625. Hasil terbaru TIMSS pada tahun 2015 menyatakan bahwa Indonesia masuk ke dalam peringkat 44 dari 49 negara. Dari hasil survei yang diperoleh, siswa Indonesia tergolong dalam kategori yang rendah (400) dalam pembelajaran matematika. Rendahnya nilai matematika siswa di Indonesia dapat disebabkan oleh banyak faktor. Salah satu faktor penyebabnya adalah kurangnya pemahaman siswa pada materi yang ada. Satu diantara banyaknya materi matematika yang dipelajari adalah materi translasi.

Translasi merupakan materi yang mempelajari tentang perpindahan semua titik pada suatu bangun dengan arahdan jarak yang sama. Materi ini diajarkan pada kelas 9 semester 1 yang menjadi salah satu bagian pokok dari materi transformasi geometri (Widiawati, 2019) . Berdasarkan hasil observasi peneliti selama proses PPL di SMP 6 Salatiga, terdapat 60 siswa dari total keseluruhan 90 siswa memiliki nilai dibawah KKM. Disamping itu ditemukan terdapat banyak siswayang lalai atau tidak mengerjakan tugas yang telah diberikan, sehingga mengakibatkan siswa tidak memahami materi translasi. Menurut hasil wawancara terhadap sebagian siswa yang tidak mengerjakan tugas, mereka mengaku kesulitan untuk memahami materi karena proses pembelajaran yang dilakukan secara daring membuat siswa kurang memperhatikan materi serta kesulitan untuk menggunakan rumus translasi pada soal yang diberikan oleh guru.

Pada penelitian (Ilyas, 2015) menjelaskan bahwa terdapat 5 jenis kesulitan belajar siswa dalam mata pelajaran matematika, yaitu kemampuan siswa tidak dapat menangkap materi yang abstrak, hanya dapat menangkap materi yang nyata dalam dunia. Kedua siswa hanya dapat menulis dan menyebutkan simbol, tetapi tidak dapat menggunakannya. Akibatnya simbol tersebut tidak dapat 
dipahami oleh siswa di dalam kalimat matematika. Selanjutnya siswa mengerti rumus dan dapat menggunakannya, tetapi tidak paham dalam hal apa prinsip itu dapat digunakan. Keempat kurangnya kemampuan siswa dalam memahami ketidaksamaan penggunaan operasi dan prosedur pada materi yang lebih awal dapat mempengaruhi pemahaman operasi dan prosedur pada materi selanjutnya. Serta yang terakhir adalah pengetahuan siswa yang kurang akan menghambat dalam memecahkan masalah dalam matematika, sementara itu materinya berlanjutsecara bertahap.

Dari penjelasan tersebut maka dapat disimpulkan bahwa kemampuan siswa dalam memahami materi yang bersifat abstrak serta penanaman pemahaman konsep dari guru pada siswa masih dinilai kurang. Selain permasalahan tersebut, kondisi sekarang yang sedang mengalami pandemi Covid-19 membuat siswa sangat tidak efisien dalam proses pembelajaran. UNESCO menanggapi bahwa penyakit Covid-19 membuat dampak yang besar pada dunia pendidikan, sekitar hampir 300 juta siswa di dunia mengalami kendala dalam kegiatan sekolah serta mengakibatkan hak-hak pendidikan siswa di masa depan terancam (Dewa, Mukin, \& Pandango, 2020) . Permasalahan tersebut dapat diatasi menggunakan berbagai inovasi dalam proses pembelajaran dengan membuat berbagai materi abstrak menjadi lebih nyata serta menguatkan pemahaman konsep siswa. Salah satu inovasi yang dapat digunakan yaitu dengan menggunakan media pembelajaran. Media pembelajaran adalah alat bantu yang digunakan untuk menjelaskan materi pembelajaran yang susah dijelaskan secara langsung (Musfiqon, 2012) . Menurut Briggs (Anitah, 2012), dalam proses pembelajaran, media menjadi sebuah alat bantu fisik untuk menjelaskan atau menyempurnakan konten pembelajaran. Dengan kata lain, media menjadi alat bantu yang digunakan dalam proses pembelajaran untuk menyempurnakan konten dari pembelajaran itu sendiri.

Salah satu media pembelajaran yang dapat menjadi alternatif membantu pemahaman siswa untuk memahami mata pelajaran matematika adalah GeoGebra Classroom. GeoGebra Classroom merupakan pengembangan dari aplikasi GeoGebra yang diciptakan oleh Markus Hohenwarter. Aplikasi GeoGebra memiliki tujuan untuk membantu siswa dan tenaga pengajar untuk mempermudah dalam proses belajar aljabar, geometri, kalkulus dan statistika (Bu \& Schoen, 2011). Pada penelitian (Anggraeni, Ma'arufi, \& Suaedi, 2021) menunjukan bahwa penggunaan aplikasi GeoGebra sangat berguna dan dinilai efektif dalam pembelajaran matematika. Dalam perkembangannya aplikasi GeoGebra membuat salah satu fitur terbaru yaitu GeoGebra Classroom. GeoGebra Classroom merupakan platform virtual yang memiliki tujuan sama seperti induk aplikasinya yaitu GeoGebra dengan kelebihan yang dimilikinya yaitu dapat diakses melalui website serta dapat memberikan tugas yang lebih menarik dan interaktif bagi siswa (Amiudi, et al., 2021). Selain penggunaan aplikasi GeoGebra, penerapan konsep yang tepat juga mampu mempengaruhi tingkat pemahaman konsep siswa.

Pada penelitian ini peneliti menggunakan metode penelitian National Council of Teacher of Mathematics (NCTM). Metode NCTM merupakan salah satu metode yang dapat digunakan untuk meningkatkan pemahaman konsep siswa dalam pembelajaran matematika. Dalam penerapannya 
metode pembelajaran NCTM siswa tidak sekedar memiliki pemahaman konsep yang kuat pada suatu materi saja, namun siswa juga akan dilatih agar memiliki kemampuan untuk menyelesaikan suatu masalah/soal pada materi yang telah dipelajari (Maulyda, 2020) . NCTM dalam (Hikmah, 2017) juga menjelaskan bahwa kemampuan dari pemahaman matematis menjadi hal yang penting dalam prinsip pembelajaran matematika. Sehingga hasil dari pembelajaran tersebut akan sangat berguna bagi siswa di kemudian hari. Dalam ((NCTM), 2000) terdapat tujuh standar proses pada pembelajaran matematika menurut pemahaman konsep NCTM, antara lain mendeskripsikan konsep secara tulisan dan lisan, penggunaan diagram atau model atau simbol untuk merepresentasikan suatu konsep, memberi contoh dan bukan contoh dari konsep, mengidentifikasi sifat-sifat suatu konsep, mengenal berbagai makna dan pemahaman konsep, mengenal syarat-syarat yang menentukan suatu konsep.

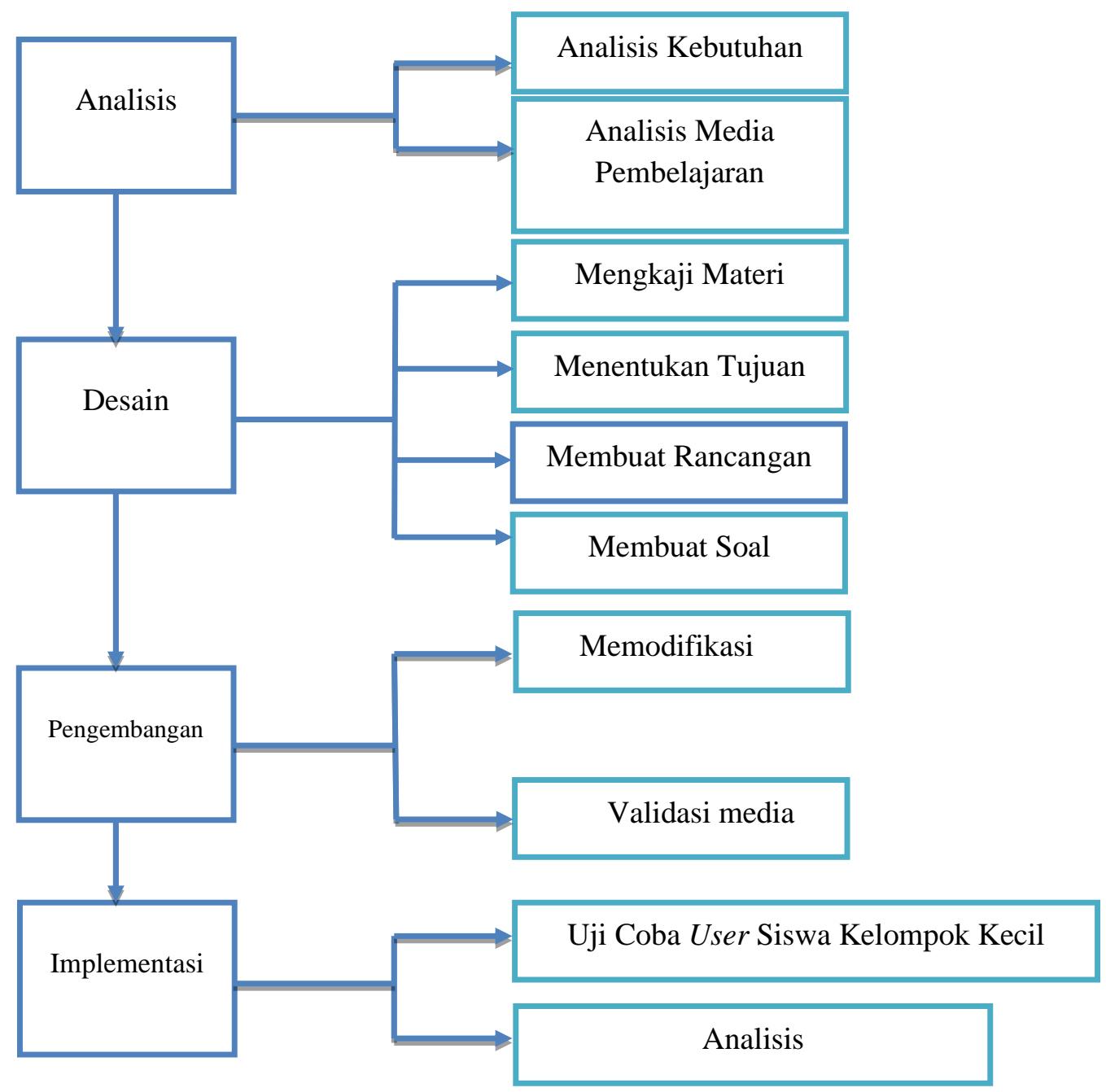

Gambar 1. Bagan alur penelitian

\section{METODE}

Penelitian ini merupakan jenis penelitian Research and Development (RnD) atau juga biasa disebut penelitian pengembangan. Penelitian pengembangan ini menggunakan model ADDIE yang 
terdiri dari 5 tahapan di dalamnya yaitu analisis, desain, pengembangan, implementasi dan evaluasi. (Branch, 2009) berpendapat bahwa model ADDIE ini memiliki filosofi Pendidikan yaitu bahwa pusat dari keinginan dan niat untuk belajar seharusnya ada pada diri siswa sendiri yaituadanya tanda-tanda seperti inovatif, autentik dan inspirasional. Pada setiap tahapan dari model penelitian ADDIE dapat dilakukan pengulangan untuk pada setiap fasenya, sehingga akan memungkinkan untuk dilakukan revisi di setiap fase penelitian.

Sedangkan media pembelajaran yang digunakan pada penelitian ini adalah GeoGebra Classroom pada materi translasi siswa kelas IX SMP. Sebelum dilakukan sebuah penelitian, media GeoGebra Classroom harus divalidasi terlebih dahulu. Tujuan dari validasi tersebut untuk memperoleh penilaian mengenai tampilan dan cakupan materi yang berikan. Hasil penilaian/validasi dari reviewer digunakan sebagai pedoman untuk dilakukannya tahap revisi sehingga akan menghasilkan media yang layak uji, baik dari sisi tampilan maupun materi pembelajaran. Pada penelitian ini juga menerapkan metode NCTM agar siswa tidak hanya memiliki pemahaman konsep yang kuat pada suatu materi saja, namun ia juga akan memiliki kemampuan dalam menyelesaikan masalah pada materi yang telah dipelajari (Maulyda, 2020). Uji coba yang dilakukan pada penelitian ini bersifat terbatas serta media ini lebih mengedepankan untuk proses pembelajaran siswa kelas IX SMP. Namun tidak menutup kemungkinan dapat digunakan pula pada jenjang pendidikan lainnya.

\section{HASIL DAN DISKUSI}

Sesuai dengan model ADDIE, langkah-langkah pembuatan media website pada materi translasi adalah sebagai berikut:

\section{Analyze (Analisis)}

Tahap awal dalam penelitian ini peneliti melakukan analisis pada beberapa media pembelajaran yang berbasis teknologi. Dari berbagai media yang peneliti temukan, peneliti memilih satu media pembelajaran yang berbasis website, yaitu GeoGebra Classroom. Media GeoGebra Classroom ini dinilai lebih praktis serta dapat digunakan melalui perangkat handphone maupun komputer pada masing-masing siswa. Di samping itu untuk akses GeoGebra Classroom juga hanya menggunakan koneksi internet yang sedikit serta tidak menghabiskan banyak ruang penyimpanan pada perangkat.

\section{Design (Desain)}

Pada tahap desain ini peneliti mempelajari setiap topik masalah dan mencoba untuk menemukan solusi alternatif melalui setiap langkah analisis. Langkah-langkah desain yang digunakan adalah sebagai berikut:

1. Mengkaji Materi

Berdasarkan hasil analisis materi yang telah dilakukan peneliti, materi yang akan diberikan pada soal di dalam media GeoGebra Classroom adalah materi translasi. Materi tersebut merupakan sub bab dari materi TransformasiGeometri yang diberikan pada siswa kelas IX SMP. 


\section{Menentukan Tujuan Belajar}

Pengembangan media GeoGebra Classroom pada materi translasi yang diberikan telah disesuaikan berdasarkantujuan belajar siswa pada kurikulum 2013. Dalam tujuan belajar, terdapat tujuh pengalaman belajar yang akan dimiliki oleh siswa, antara lain: (1) siswa memiliki keterampilan dalam mengerjakan tugas belajar matematika; (2) siswa dapat mengembangkan dan menunjukkan sikap aktif, bekerjasama serta toleran dalam proses pembelajaran secara individu maupun kelompok; (3) siswa dapat menunjukkan sikap yang kritis ketika proses pembelajaran melalui kegiatan tanya jawab; (4) siswa dapat menganalisis suatu permasalahan yang berkaitan dengan materi translasi; (5) siswa dapat menemukan suatu konsep translasi di dalam kehidupan sehari-hari; (6) siswa dapat menerapkan rumus yang terdapat pada materi translasi untuk pembuktian masalah matematika; (7) siswa mampu menerapkan materi translasi untuk menyelesaikan suatu permasalahan matematika. Media pembelajaran yang berbasis website ini akan didesain oleh peneliti agar siswa mendapatkan tujuh pengalaman belajar tersebut.

3. Membuat Rancangan Media

Peneliti membuat rancangan media dengan soal dan aplikasi GeoGebra yang akan digunakan pada website GeoGebra Classroom. Selain itu peneliti juga membuat rancangan agar media mudah dipahami dan mudahdigunakan selama proses pembelajaran berlangsung.

\section{$\equiv$ GeoGebra}

Aktivitas 3 - Translasi pada sebuah Garis

Perhatikan geogebra dibawah ini untuk mengerjakan soal nomer 1 dan 2

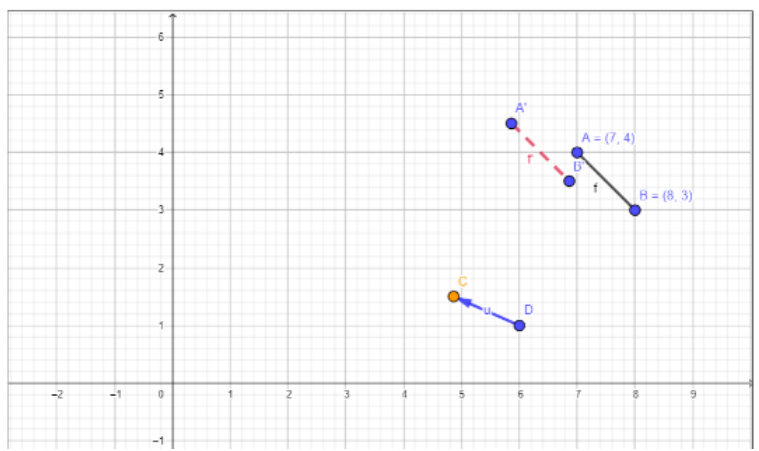

Gambar 2. Desain GeoGebra

4. Membuat Soal

Pada langkah ini, peneliti membuat soal sesuai dengan poin-poin yang ada pada metode pemahaman konsep NCTM. Terdapat 7 poin yaitu:

a. Mendeskripsikan konsep secara tulisan dan lisan, disini siswa diharapkan mampu untuk memahami konsep daritranslasi dan mampu menjelaskan definisi translasi menurut pengertian 
siswa.

b. Memberikan contoh dan bukan contoh dari suatu bentuk konsep, siswa diharapkan dapat memberikan contoh lain yang belum ada di materi.

c. Penggunaan diagram atau model atau simbol untuk merepresentasikan dari suatu konsep, siswa diharapkan mampuuntuk menyelesaikan soal aplikasi dari Geogebra

d. Mengubah suatu bentuk representasi ke bentuk lainnya, siswa diharapkan dapat mengubah suatu bentuk pertanyaan ke dalam bentuk jawaban matematika

e. Mengenal berbagai makna dan pemahaman konsep, siswa diharapkan mampu untuk memahami berbagaikonsep translasi.

f. Mengidentifikasi sifat-sifat dari suatu konsep, siswa mampu menjelaskan sifat-sifat dari translasi sesuai pengertiansiswa

g. Mengenal syarat-syarat yang menentukan suatu konsep dan membandingkan serta membedakan suatu konsep, disini siswa diminta untuk membandingkan konsep translasi dan konsep refleksi

\section{Development (Pengembangan)}

Pada tahap pengembangan ini peneliti melakukan mempersiapkan perangkat pembelajaran yang nantinya akan digunakan pada proses pembelajaran. Dalam tahapan ini peneliti melakukan beberapa kegiatan yaitu perancangan, pembuatan soal, mengembangkan/memodifikasi media GeoGebra Classroom. Langkah-langkah pada tahap pengembangan ini adalah:

\section{Memodifikasi Website}

Setelah peneliti membuat akun pada GeoGebra Classroom, kemudian membuat kelas dan mengupload setiap pertanyaan yang sudah dibuat menurut pemahaman konsep NCTM. Pertama membuat tampilan pada GeoGebra Classroom terlihat menarik untuk media pembelajaran siswa.

Setelah peneliti mendapatkan website yang ada, kemudian mendesain website sesuai dengan kebutuhan. Proses desain diawali dengan membuat folder translasi. setelah membuat folder translasi kemudian membuat 3 lembar aktivitas yang akan dipakai. Aktivitas ini merupakan materi yang akan dipelajari oleh siswa. Pada aktivitas pertama terdapat materi translasi pada sebuah titik, aktivitas kedua siswa mempelajari translasi pada sebuah garis dan pada aktivitas ketiga siswa mempelajari translasi pada sebuah bangun.

Selanjutnya pada setiap aktivitas akan diupload materi pembelajaran dan soal yang akan dikerjakan oleh siswa. Pada setiap aktivitas juga akan diupload aplikasi GeoGebra yang akan dipakai siswa sebagai media interaktif, pada saat siswa menggunakan GeoGebra sudah terdapat cara penggunaan pada setiap GeoGebra di semua aktivitas. Selain terdapat aplikasi GeoGebra, di setiap aktivitas juga terdapat berbagai soal yang harus dikerjakan oleh siswa. Ketika siswa sudah menjawab soal yang diberikan dan jawaban yang dikerjakan siswa salah maka akan muncul jawaban yang benar dari aplikasi GeoGebra Classroom. Dari jawaban tersebut dapat menjadi evaluasi mandiri bagi siswa. Hasil lembar kerja GeoGebra Classroom dapat dilihat pada gambar 
Pengembangan Media Pembelajaran GeoGebra Classroom Sebagai Penguatan Pemahaman Konsep Materi Translasi Siswa Smp Kelas IX, Naomi Angeltia Sutopo, Novisita Ratu

berikut.

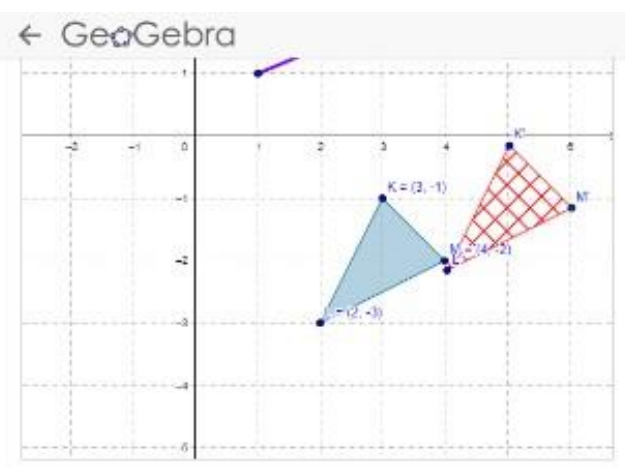

Cara kerja media di atas : tarik ujung anak panah (lingkarang orange) Grsuai pentunjuk di bawah ini, setelah mengerjakan Jangan lupa kllk tanda replace agar titlk KLM kemball pada koordlnat awal.

Pongaturan Aktintas i

Gambar 3. Aplikasi GeoGebra

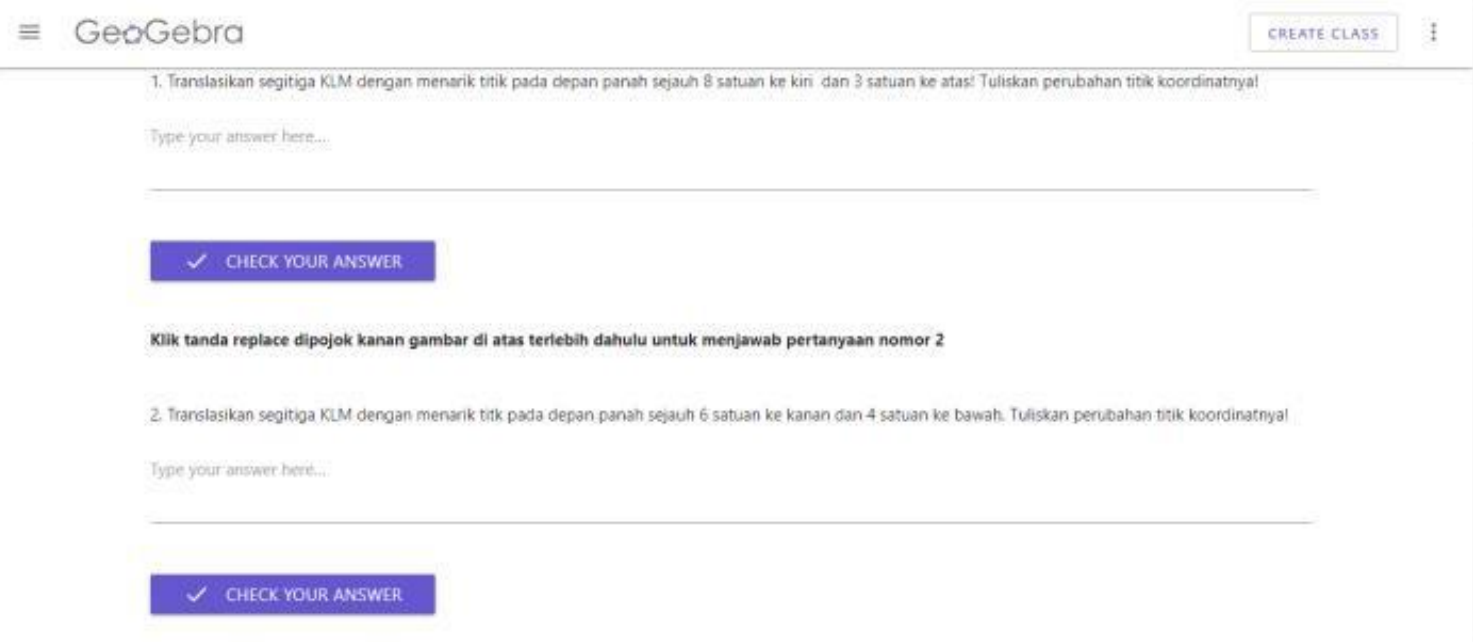

Gambar 4. Soal Latihan

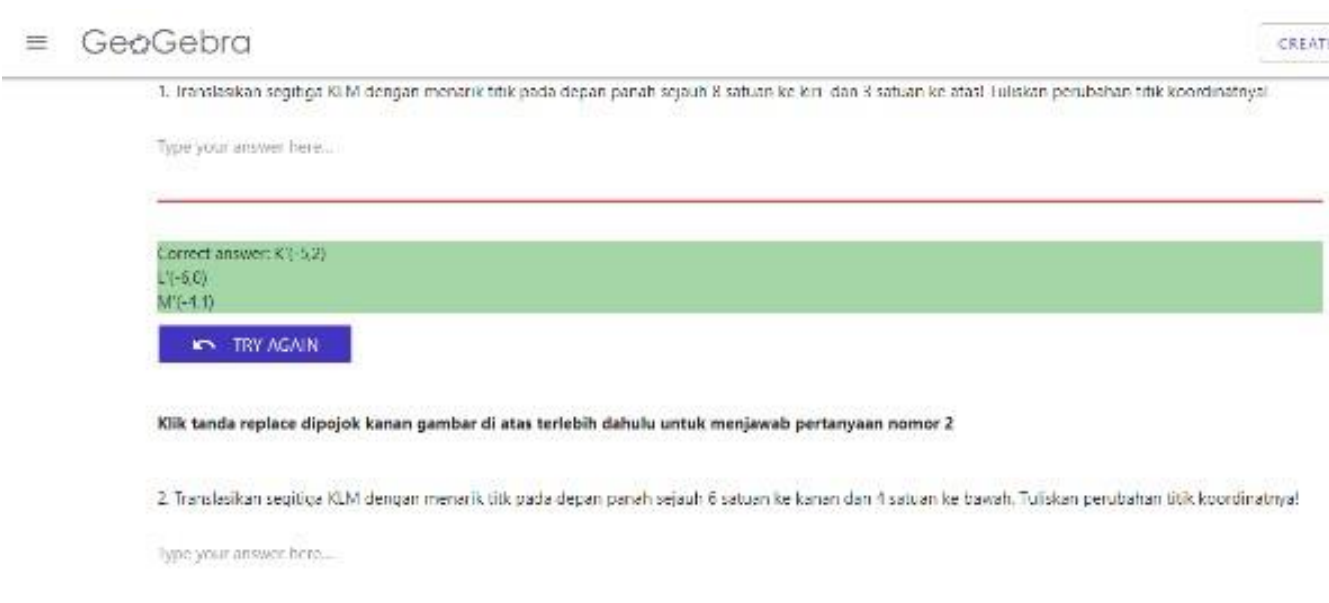

Gambar 5. Jawaban Soal Latihan 
2. Validasi media

Pada tahap ini dilakukan validasi pada media website GeoGebra Classroom untuk menguji kelayakan media. Pada penelitian ini proses validasi menggunakan instrumen yang telah disusun oleh peneliti dan telah melalui proses persetujuan oleh dosen pembimbing dan guru SMP.

Pada tahap ini, dilakukan proses validasi terhadap media website GeoGebra Classroom. Pada penelitian ini, proses validasi menggunakan instrumen yang telah disusun seta disetujui oleh dosen pembimbing dan guru SMP. Untuk menilai validitas dari aplikasi yang digunakan dapat dilihat berdasarkan dua aspek yaitu aspek materi dan aspek tampilan. Pada lembar penilaian validasi tersebut terdapat 12 indikator aspek materi serta 8 indikator pada aspek tampilan. Tahap validasi dilaksanakan bertujuan agar media GeoGebra Classroom yang telah dikembangkan oleh peneliti mendapatkan kritik atau saran dari validator yang memang ahli dalam bidangnya dan mampu menjadi bukti bahwa media GeoGebra Classroom layak digunakan sebagai media penelitian. Daftar validator terdapat pada Tabel 1.

Tabel 1 Daftar Validator

\begin{tabular}{|c|l|l|}
\hline No & \multicolumn{1}{|c|}{ Nama } & \multicolumn{1}{c|}{ Keterangan } \\
\hline 1 & Danang Setyadi, S. Pd., M.Pd & Dosen Pendidikan Matematika \\
\hline 2 & Mitchella Sinta Larasati & Guru SMP Petra 3 Surabaya \\
\hline
\end{tabular}

\section{Implementation (Implementasi)}

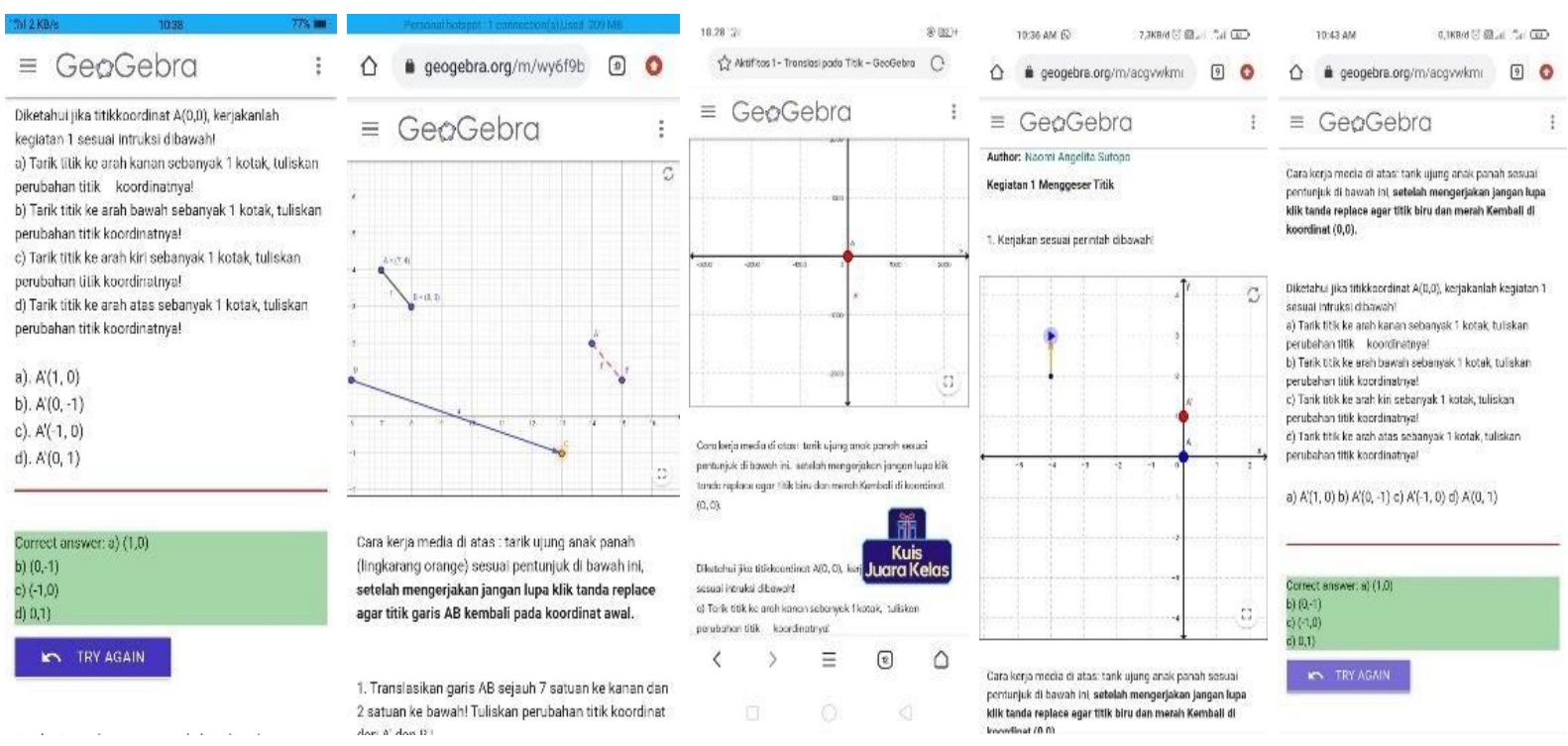

Gambar 6. Hasil Pekerjaan Siswa di Geogebra Classroom

Setelah tahap validasi selesai peneliti melanjutkan untuk menguji coba media GeoGebra Classroom pada siswa. Uji coba dilaksanakan secara online melalui pertemuan ZOOM, pada 15 siswa kelas IX SMP yang berasal dari dua sekolah yang berbeda. Sebelum melakukan uji coba siswa terlebih dahulu mengerjakan soal pretest untuk mengukur kemampuan siswa pada materi translasi sebelum menggunakan media GeoGebra Classroom. Setelah mengerjakan soal pretest, siswa dan 
peniliti melakukan proses pembelajaran materi translasi menggunakan media GeoGebra Classroom. Pada saat proses pembelajaran berlangsung siswa harus mengerjakan 3 aktivitas untuk menyelesaikan proses pembelajaran. Aktivitas yang pertama adalah mengerjakan materi translasi pada sebuah titik, aktivitas yang kedua mengerjakan materi translasi pada sebuah garis dan aktivitas yang terakhir siswa mengerjakan materi translasi pada sebuah bidang. Soal-soal yang terdapat pada ketiga aktivitas itu merupakan soal-soal yang telah sesuai dengan poin-poin yang ada pada metode pemahaman konsep NCTM dan telah disetujui dosen pembimbing maupun validator.

Gambar di atas merupakan hasil pekerjaan siswa pada media GeoGebra Classroom. Dapat dilihat dari gambar bahwa media bekerja dengan baik, disamping itu siswa juga dapat mengerjakan soal yang telah diberikan dengan baik. Setelah siswa selesai mengerjakan ketiga aktivitas menggunakan media GeoGebra Classroom,siswa mengerjakan soal posttest untuk mengukur kemampuan siswa pada materi translasi setelah menggunakan media GeoGebra Classroom.

\section{Evaluation (Evaluasi)}

Tahap selanjutnya merupakan tahap evaluasi yang bertujuan untuk menilai hasil prestasi siswa, strategi, dan media GeoGebra Classroom yang telah dikembangan. Dengan adanya tahap evaluasi ini maka peneliti dapat memberikan revisi serta memperbaiki media GeoGebra Classroom sehingga hasilnya siap untuk diuji cobakan. Hasil dari evaluasi yang telah dilakukan adalah sebagai berikut.

1. Analisis Validitas Data

Untuk melakukan analisis data validasi, peneliti menggunakan lembar instrumen peneliaian validasi untukmedia website GeoGebra Classroom, kemudian dinilai oleh validator. Terdapat dua aspek pada analisis data kevalidan antara lain sebagai berikut:

\begin{tabular}{clc}
\hline No & \multicolumn{1}{c}{ Indikator } & Item \\
\hline 1 & Kesesuaian isi dengan kompetensi dasar & 1 \\
\hline 2 & $\begin{array}{l}\text { Kesesuaian isi dengan indikator pencapaian kompetensi, dan tujuan } \\
\text { pembelajaran }\end{array}$ & 2 \\
& Kesesuaian tingkat kesulitan dan konsep materi dengan & \\
\hline 3 & perkembangan kognitif siswa. & 3 \\
\hline 4 & Sistematika pembahasan materi. & 4 \\
\hline 5 & Cakupan submateri yang lengkap dan detail & 5 \\
\hline 6 & Evaluasi yang diberikan sesuai dengan kompetensi dasar, indikator & 6 \\
& pencapaian kompetensi, dan tujuan pembelajaran. & 7 \\
\hline 7 & Tingkat kesulitan soal & 8 \\
\hline 8 & Variasi soal & 9 \\
\hline 9 & Sistematika evaluasi secara keseluruhan. & 10 \\
\hline 10 & Penggunaan bahasa baku. & 11 \\
\hline 11 & Penggunaan kalimat yang jelas dan tepat. & 12 \\
\hline 12 & Sistematika isi secara keseluruhan & \\
\hline & &
\end{tabular}

Gambar 7. Aspek Materi 
a. Aspek Materi

Gambar diatas merupakan indikator dari aspek materi yang telah divalidasi oleh validator. Pada lembar penilaian aspek materi terdapat 12 indikator. Berdasarkan hasil penilaian validator pada aspek materi, didapatkan skor rata-rata 52 dengan rerata skor untuk semua aspek sebesar 4,3 dengan kategori valid.

b. Aspek Tampilan

\begin{tabular}{clc}
\hline No & \multicolumn{1}{c}{ Indikator } & Item \\
\hline 1 & Tampilan menarik dan mendorong siswa untuk belajar & 1 \\
\hline 2 & Pemilihan jenis dan ukuran ikon dan huruf yang tepat dalam media & 2 \\
\hline 3 & Pemilihan warna media yang sesuai & 3 \\
\hline 4 & Kemudahan membaca teks atau tulisan & 4 \\
\hline 5 & Kemampuan media dapat menambah pengetahuan dengan adanya & 5 \\
& gambar, dan video & \\
\hline 6 & Kemudahan dan kelancaran dalam mengakses dan mengoperasikan & 6 \\
\hline 7 & Dukungan media bagi kemandirian belajar siswa & 7 \\
\hline 8 & Kemampuan media dalam meningkatkan pemahaman siswa & 8 \\
\hline
\end{tabular}

Gambar 8. Aspek Tampilan

Gambar diatas merupakan indikator dari aspek tampilan yang telah divalidasi oleh validator. Pada lembar penilaian aspek tampilan terdapat 8 indikator. Berdasarkan hasil penilaian validator pada aspek materi, didapatkan skor rata-rata 35,5 dengan rerata skor untuk semua aspek sebesar 4,4 dengan kategori valid.

2. Analisis Data Praktikalitas

\begin{tabular}{clc}
\hline No & \multicolumn{1}{c}{ Indikator } & Item \\
\hline 1 & Materi yang dijelaskan dalam dapat dipahami oleh siswa & 1 \\
\hline 2 & Penggunaan gambar dapat memudahlan siswa dalam belajar & 2 \\
\hline 3 & Kalimat dalam penjelasan materi dan evaluasi mudah dipahami siswa & 3 \\
\hline 4 & $\begin{array}{l}\text { Siswa menjadi lebih antusias dalam pembelajaran karena menarik perhatian } \\
\text { siswa }\end{array}$ & 4 \\
\hline 5 & $\begin{array}{l}\text { Penggunaan media oleh siswa dalam memanfaatkan waktu luang untuk } \\
\text { belajar mandiri }\end{array}$ & 5 \\
\hline 6 & Penggunaan media tidak terbatas waktu dan tempat & 6 \\
\hline 7 & Media sebagai bahan ajar tambahan dalam proses pembelajaran & 7 \\
\hline 8 & Pengembangan media tidak memerlukan biaya yang mahal & 8 \\
\hline 9 & Media menambah manfaat komputer/laptop atau handphone & 9 \\
\hline 10 & $\begin{array}{l}\text { Peningkatan pemahaman konsep siswa mampu meningkatkan hasil belajar } \\
\text { siswa setelah menggunakan media }\end{array}$ & 10 \\
\hline
\end{tabular}

Gambar 9. Aspek Kepraktisan 
Berdasarkan hasil analisis dari penelitian ini, maka media GeoGebra Classroom masuk dalam kategori praktis dengan rata-rata skor 43,5 dan nilai rerata skor untuk semua aspek 4,4. Penilaian ini berdasarkan analisis data kepraktisan yang menggunakan instrumen kepraktisan untuk GeoGebra Classroom.

\section{Analisis Data Keefektifan}

Sebelum dilakukan uji coba siswa diambil nilai pretest, dilanjutkan dengan memainkan GeoGebra Classroom sekitar 120 menit, diakhiri dengan posttest dan pengisian lembar respon siswa. Hasil dari pretest dan posttest dapat dilihat sebagai berikut.

\begin{tabular}{llrr}
\multicolumn{4}{c}{ Statistics } \\
\hline \multicolumn{3}{c}{ Pre-Test } & Post-Test \\
\hline \multirow{2}{*}{$\mathrm{N}$} & Valid & 15 & 15 \\
\cline { 2 - 4 } & Missing & 0 & 0 \\
\hline \multicolumn{2}{l}{ Mean } & 63.33 & 95.93 \\
\hline Minimum & 30 & 83 \\
\hline Maximum & 100 & 100
\end{tabular}

Gambar 10. Hasil dari Pretest dan Posttest

Berdasarkan Tabel 2 Hasil dari Pretest dan Posttest, Terlihat bahwa hasil rata-rata posttest $(95,93)$ lebih baik dari rata-rata pretest $(63,33)$. Untuk mengetahui apakah media pembelajaran GeoGebra Classroom efektif dilakukan pengolahan data pretest dan posttest. Hal pertama yang perlu dilakukan adalah melakukan uji normalitas.Hasil uji normalitas dapat dilihat sebagai berikut.

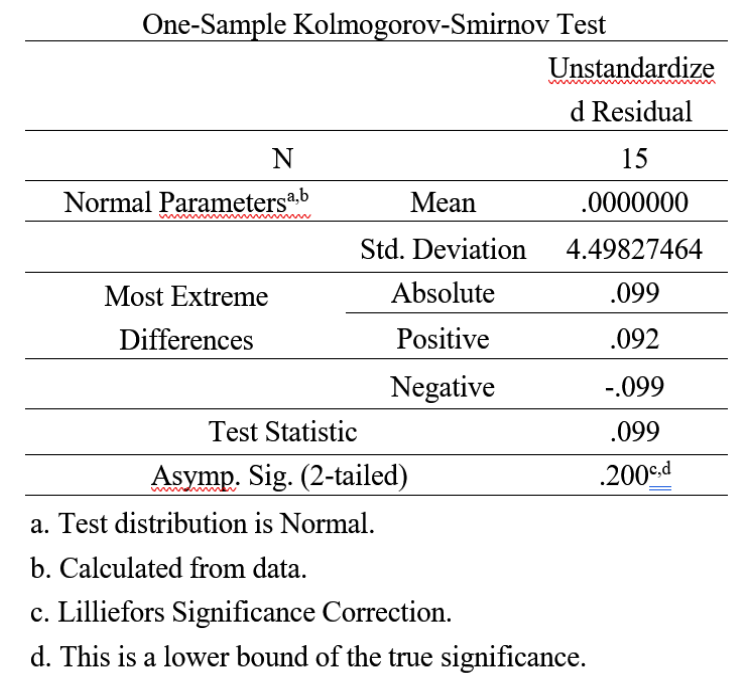

Gambar 11. Hasil Uji Normalitas

Mengacu pada hasil Uji Normalitas sebelumnya, di penelitian ini menggunakan subjek sebanyak 15 orang siswa maka hasil signifikan yang dilihat adalah hasil dari uji normalitas menggunakan Kolmogorov-Smirnov. Hasiluji normalitas menunjukan nilai signifikan 0,200 (lebih 
dari 0,05), sehingga dapat dinyatakan bahwa nilai residu berdistribusi normal. Sampel tersebut dapat digunakan untuk uji paired sample t-test. Hasil uji paired sample t-test dapat dilihat sebagai berikut.

\begin{tabular}{|c|c|c|c|c|c|c|c|c|c|}
\hline \multicolumn{10}{|c|}{ Paired Samples Test } \\
\hline & & \multicolumn{5}{|c|}{ Paired Differences } & $\mathrm{t}$ & $\mathrm{df}$ & $\begin{array}{l}\text { Sig. (2- } \\
\text { tailed) }\end{array}$ \\
\hline & & \multirow[b]{3}{*}{ Mean } & \multirow{3}{*}{$\begin{array}{c}\text { Std. } \\
\text { Deviatio } \\
\text { n }\end{array}$} & \multirow{3}{*}{$\begin{array}{l}\text { Std. } \\
\text { Error } \\
\text { Mean }\end{array}$} & \multirow{2}{*}{\multicolumn{2}{|c|}{$\begin{array}{l}\text { 95\% Confidence } \\
\text { Interval of the } \\
\text { Difference }\end{array}$}} & & & \\
\hline & & & & & & & & & \\
\hline & & & & & Lower & Upper & & & \\
\hline \multirow[t]{3}{*}{ Pair 1} & Pre-Test & & & & & & & & \\
\hline & -Post- & -32.600 & 21.444 & 5.537 & -44.475 & -20.725 & -5.888 & 14 & .000 \\
\hline & Test & & & & & & & & \\
\hline
\end{tabular}

Gambar 12. Hasil Uji Paired Sampel T-Test

Hasil pengolahan uji paired sample t-test menunjukan sig. (2-tailed) dari pretest dan posttest memiliki nilai 0,000 kurang dari 0,05 atau rata-rata pretest dan posttest adalah berbeda. Nilai signifikansi kurang dari 0,05 dengan hasil belajar pada posttest $(95,93)$ lebih baik dari pretest $(63,33)$, sehingga media ini dapat disebut efektif digunakan untuk menjadi media pembelajaran pada materi translasi untuk tingkat SMP.

\section{KESIMPULAN}

Berdasarkan hasil penelitian yang telah disampaikan diatas, dapat diketahui bahwa media pembelajaran dengan menggunakan GeoGebra Classroom pada materi translasi dinilai efektif dan praktis dalam meningkatkan kemampuan pemahaman konsep belajar matematika siswa SMP kelas IX. Berdasarkan hasil penilaian diperoleh rata-rata 44 dengan rerata skor untuk semua aspek adalah 4,4 dan termasuk dalam kategori tinggi. Kesimpulan yang dapat diambil berdasarkan hasil tersebut adalah media GeoGebra Classroom yang dihasilkan praktis digunakan sebagai sarana belajar siswa. Keefektifan media website GeoGebra Classroom dapat dilihat dari hasil pekerjaan siswa pada uji kemampuan awal (pretest) memperoleh nilai rata-rata 63, sedangkan hasil uji kemampuan akhir (posttest) memperoleh nilai rata-rata 96. Dilihat dari perbedaan rata-rata nilai pretest dan posttest yang signifikan, maka media GeoGebra Classroom dinilai efektif digunakan sebagai sarana belajar siswa.

Disamping itu media GeoGebra Classroom juga menarik dan memberikan pengalaman yang baru bagi siswa dalam mempelajari matematika, terlebih materi translasi. Hal ini dapat dilihat dari hasil lembar pendapat siswa bahwa media GeoGebra Classroom mampu meningkatkan kemampuan siswa dalam belajar dan siswa sangat tertarik menggunakan media GeoGebra Classroom sebagai media pembelajaran materi translasi, bahkan siswa juga berharap jika media GeoGebra Classroom diterapkan pada materi lainnya.

Dari penelitian ini peneliti memberikan saran kepada siswa agar dapat menggunakan media GeoGebra Classroom untuk membantu siswa dalam belajar matematika secara mandiri dan dapat 
meningkatkan kemauan siswa dalam belajar matematika. Selain itu penggunaan media ini dapat digunakan di sekolah dan juga di luar lingkungan sekolah. Disamping itu peneliti juga mengharapkan bahwa media GeoGebra Classroom dapat dikembangkan pada materi pembelajaran lainnya.

\section{REFERENSI}

Amiudi, M., Basir, M. A., Kusmaryono, I., Maharani, H. R., Saputro, B. A., \& Wijayanti, D. (2021). Pelatihan Penggunaan Geogebra Classroom untuk Mengoptimalkan Pembelajaran Matematika. Jurnal ABDINUS, 417-428.

Anggraeni, E. R., Ma'arufi, \& Suaedi. (2021). Pengembangan media pembelajaran matematika berbasis geogebra untuk meningkatkan kemampuan pemahaman konsep siswa. Jurnal Penelitian Matematika dan Pendidikan Matematika, 43-55.

Anitah, S. (2012). Media pembelajaran. Surakarta: Yuma Pustaka.

Branch, R. (2009). Instructional design the ADDIE approach. USA: Springer.

Bu, L., \& Schoen, R. (2011). Model-Centred Learning Pathways to:Mathematical Understanding Using geogebra. (Vol. 1). (J. M. Spector, K. Morgan, \& N. M. Seel, Eds.) Rotterdam: Sense Publisher.

Dewa, E., Mukin, M. U., \& Pandango, O. (2020). Pengaruh Pembelajaran Daring Berbantuan Laboratorium Virtual Terhadap Minat dan Hasil Belajar Kognitif Fisika. Jurnal Riset Teknologi dan Inovasi Pendidikan, 351-359.

Hikmah, R. (2017). Penerapan model advance organizer untuk meningkatkan kemampuan pemahaman siswa. Jurnal SAP, 271-280.

Ilyas, M. (2015). Deskripsi hasil belajar matematika siswa pada materi bilangan bulat ditinjau dari gaya kognitif field dependent dan field independent . Pedagogy, 77-89.

Kowiyah, S., \& Sakti, E. (2018). Perbedaan hasil belajar matematika siswa dengan menggunakan model problembased learning dan model ekspositori. 327-336.

Maulyda, M. A. (2020). Paradigma pembelajaran matematika berbasis NCTM. Malang: CV . IRDH.

Musfiqon, H. M. (2012). Pengembangan media dan sumber pembelajaran. Jakarta: Prestasi Pustakaraya.

NCTM, N. C. (2000). Principles and standards for school mathematics. Reston: VA: NCTM.

Putra, F. G. (2016). Pengaruh model pembelajaran reflektif dengan pendekatan matematika realistik bernuansa keislaman terhadap kemampuan komunikasi matematis. Jurnal Pendidikan Matematika, 203-210.

Putra, F. G. (2017). Eksperimentasi Pendekatan Kontekstual Berbantuan Hands On Activity (HoA) Terhadap Kemampuan Pemecahan Masalah Matematika. Jurnal Pendidikan Matematika, 73-80.

Widiawati. (2019). Desain pembelajaran menggunakan tessellation berbasis pendekatan saintifik pada materi translasi dan refleksi. Judika Education, 80-90. 